\title{
Response of deep-water fore-arc systems to sea-level changes, tectonic activity and volcaniclastic input in Central America
}

\author{
JUTTA WINSEMANN and HARTMUT SEYFRIED \\ Institut für Geologie und Paläontologie, Universität Stuttgart, Böblinger Strasse 72, D-7000 Stuttgart I, \\ Germany
}

\begin{abstract}
The incipient island-are system of southern Central America (Cretaccous - early Oligocene) is characterized by thick turbidite systems, which mainly filled inner fore-arc troughs. Outcrop data show four, second-order depositional sequences in the deep-water sedıments. The formation of these depositional sequences is strongly related to the morphotectonic evolution of the island-are system. Each depositional sequence reflects the complex interaction between global sea-level fluctuatıons, sediment supply, and tectonic activity.

Strong marginal uplift and high volcaniclastic sediment supply during early to late Paleocene and late Eocene times caused the formation of coarse-grained channel-lobe systems. During late Paleocene and mid-Eocene times, fine-grained, thin-bedded turbidite systems were deposited. owing to regronal subsidence and a decrease in volcanic supply. Uplift and subsidence of sediment-source areas acted as major controls on deposition of basinal cycles.
\end{abstract}

\section{INTRODUCTION}

The fore-arc area of southern Central America belongs to the middle America arc-trench system, which extends along southern Mexico and the Central American isthmus. The Cocos plate is being subducted beneath the North American and Caribbean plates (Burbach et al., 1984) and is currently being subducted beneath Costa Rica at $9 \mathrm{~cm} /$ yr (see Fig. 1 in paper by Seyfried et al.)

Subduction and related processes in southern Central America started in Late Cretaceous times. The incipient island-arc system is characterized by narrow structural basins in the inner fore-arc area, an outer arc, and a trench slope system (Fig. 1).

The sediments of the ophiolitic basement (Nicoya Complex) are mainly pelagic deposits and consist of radiolarian cherts, black shales, and deep-water limestones of Late Jurassic to Late Cretaceous age (Schmidt-Effing, 1979; Lundberg, 1982; Baumgartner et al. 1984; Gursky, 1984; Astorga, 1987).

From Maastrichtian to Eocene times, thick successions of volcaniclastic turbidites were deposited in the inner fore-arc basins, while thin-bedded. cal- careous turbidites and slump deposits prevaled in the outer fore-arc basins. The shape of these sedimentary basins was probably controlled by a major strike-slip system, which transected the island arc perpendicularly in the region of central Costa Rica. A broader discussion of the regional geological setting is given in the chapter by Seyfried $e t$ al.

Because modern and ancient submarine fans show great variability in shape and facies relationship, the type and timing of turbidite events have been discussed recently by many authors with regard to sediment supply, tectonic activity, and sealevel fluctuation (Barnes \& Normark, 1985; Mutti, 1985; Shanmugam et al., 1985; Stow et al., 1985; Mutti \& Normark, 1987; Kolla \& Macurda, 1988: Shanmugam \& Moiola, 1988). Classifications of submarine fans have been compiled, based on their tectonic setting (Mutti \& Normark, 1987; Shanmugam \& Moiola, 1988).

According to the sequence-stratigraphic model, the development of submarine fans is mannly related to global sea-level lowstands and they form part of 


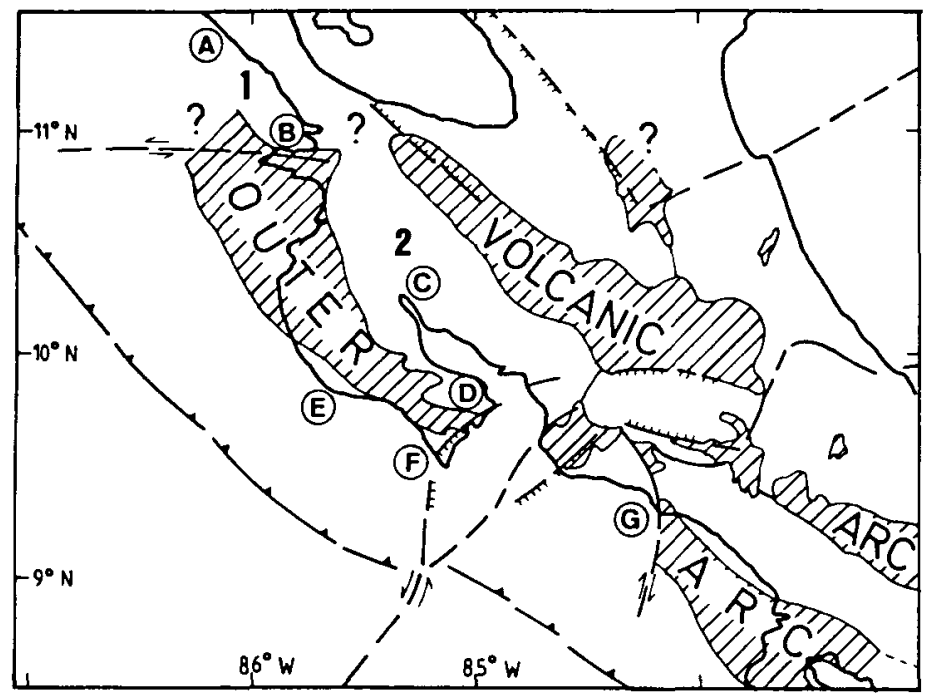

Fig. 1. Tectonic setting and location map of Upper Cretaceous to upper Eocene turbidite systems of the fore-arc area of Costa Rica and southwest Nicaragua (modified after Astorga et al., 1989). Inner fore-arc basins: (1) Nicaragua Trough (A, southwest Nicaragua; B. Bahı Salınas); (2) Tempisque Trough (C. Barbudal; D. Curú). Outer fore-arc basins: E, Sámara Basin: F, Cabo Blanco Basin; G, Quepos

Basin. For location of figure within Central America, compare with Fig. 2 of the paper by Seyfricd et al. this volume.

the lowstand systems tract. This lowstand systems tract can be divided into a lowstand fan (basin-floor fan) and a lowstand wedge (Posamentier \& Vail, 1988). The lowstand fan is characterized by the deposition of sand lobes, whereas the subsequent lowstand wedge is dominated by channel-fill deposits and finer grained, wedge-shaped slope deposits. The lowstand wedge has also been described as slope fan, slope-front fill, and wedge and cone (Mitchum, 1985; Vail \& Sangree, 1988). In contrast, carbonate platform environments suggest that the sedimentary response to relative sea-level changes in these systems is opposite to that observed in siliciclastic systems (Sarg, 1988; Dolan, 1989). During highstands, mud- and sand-size carbonate sediment is shed off the platform and transported into the adjacent basin, whereas conversely, during sea-level lowstands. the production capability of shallow water carbonate is strongly reduced and subaerial exposure of platforms may result in meteoric cementation and karstification (Sarg. 1988). In hybrid siliciclasticcarbonate basinal cycles, carbonate deposition therefore reflects conditions of relative highstands of sea level, whereas lowstands of sea level are documented by siliciclastic sedimentation. In contrast, small to moderate falls of sea level in ramp settings may expose only the inner part of the ramp, resulting in lowstand deposition of mixed siliciclasticallodapic carbonate sedıments (Dolan, 1989).

Another model was presented by Mutti (1985), who distinguished three types of turbidite system, type I, type II, and type III (Fig. 2), which more recently were related to the long-term stability of basins (Mutti \& Normark, 1987). Active-margin fans are considered usually to be small, coarsegrained systems, owing to proximal sources, narrow shelves, and coastal plains (Mutti \& Normark, 1987; Shanmugam \& Moiola, 1988). However, in the study area, small, sand-rich fans only occur in lower Paleocene and upper Eocene deposits, whereas finegrained, thin-bedded turbidite systems formed from late Paleocene to mid-Eocene times.

\section{DEPOSITIONAL SEQUENCES IN THE INNER FORE-ARC TROUGHS}

The inner fore-arc area comprises two major basinfill systems: (1) Upper Cretaceous to upper Eocene turbidite systems of the Nicaragua Trough and (2) Upper Cretaceous to upper Eocene turbidite systems of the Tempisque Trough (Fig. 1).

Outcrop data show four second-order depositional sequences in the deep-water sediments, which range considerably in size, geometry and location. Each depositional sequence is characterized by a particular association of turbidite systems, which reflect the prevailing local conditions of sediment supply, tectonic activity, and global sea-level fluctuations during Late Cretaceous to Eocene times (Fig. 3). 
SAND DEPOSIION IS MAINL RESIRICIED TO CHANNEL-FHL SEOUENCES

TYPE Ш

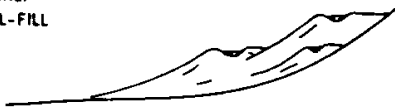

SAND IS DEPOSITED IN BOTH CHANNEL - FILL AND IOBE SEOUENCES

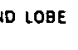

"

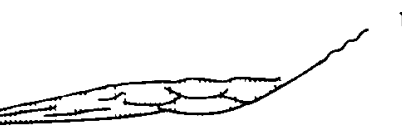

IYPE II
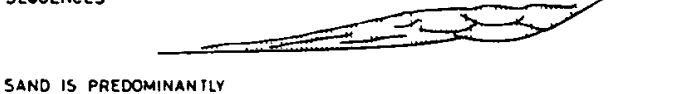

SANO IS PREDOMINANILY
DEPOSIIEO IN NON -

CHANNELIZEO LOBES

TYPE I

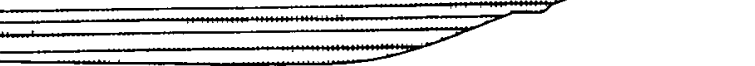

Fig. 2. Comparison of Mutti's depositional systems and the lowstand systems tract of the scquence-stratigraphic model. The type I turbidite system corresponds to the basin-floor fan, the type II and type III systems correspond to the lowstand wedge (also called slope fan or prograding wedge). (A) Simplified after Mutti \& Normark (1987). (B) Simplified after Vail \& Sangree (1988).

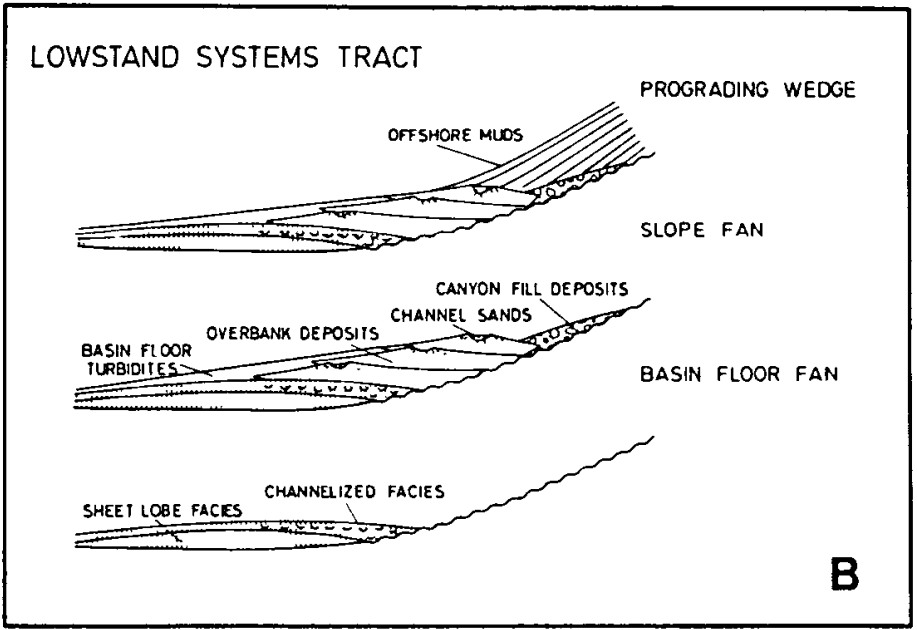

\section{Nicaragua Trough}

The deposits of the Nicaragua Trough are mainly exposed along the Pacific coast of southwest Nicaragua and northern Costa Rica and were recorded in two major sections (A, B, Fig. 1).

Large-scale subsidence of the southern hasin margin is recorded by thickness variations and facies development of turbidite systems from Late Creaceous to Eocene times. The greatest thickness of the basinal sequence occurs in the northern part of the Nicaragua Trough (section A), where almost $6000 \mathrm{~m}$ of deep-water sediments are recorded. Thick- ness decreases strongly to the south and is only about $3000 \mathrm{~m}$ in section $B$.

\section{Section A}

In southwest Nicaragua, Upper Cretaceous to Paleocene rocks crop out only in poor inland exposures and are mainly recorded from well data (Anonymous. 1972, cited in Weyl. 1980). According to Weyl (1980) these deposits mainly consist of about $3500 \mathrm{~m}$ of silıciclastic turbidites and tuffaceous shales. 
A

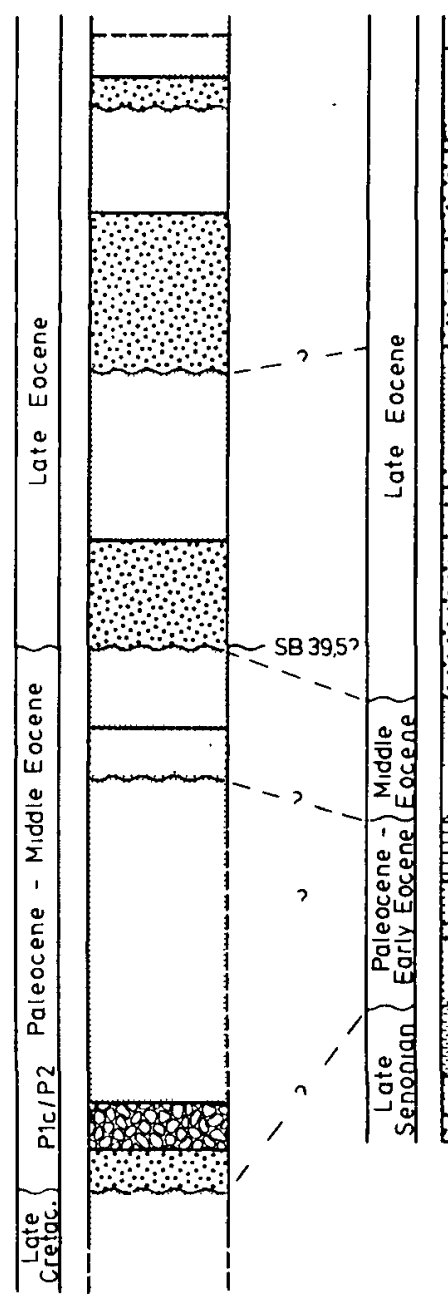

B

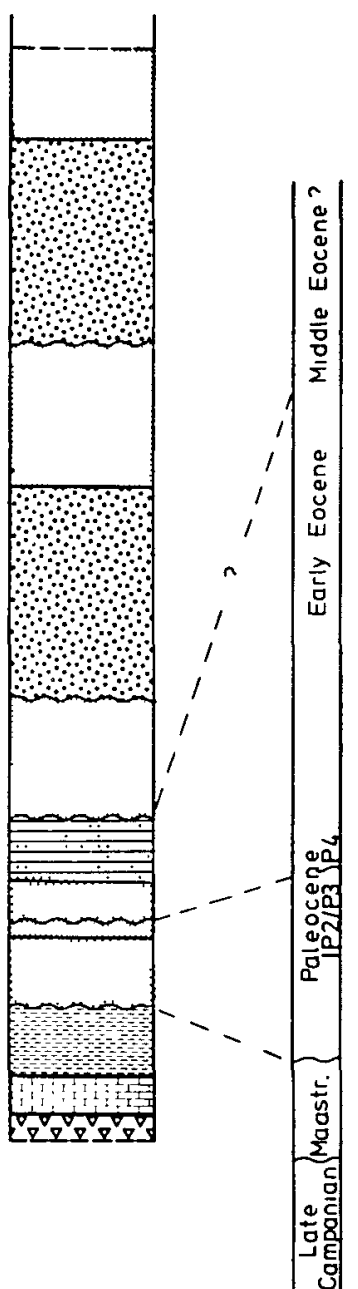

C

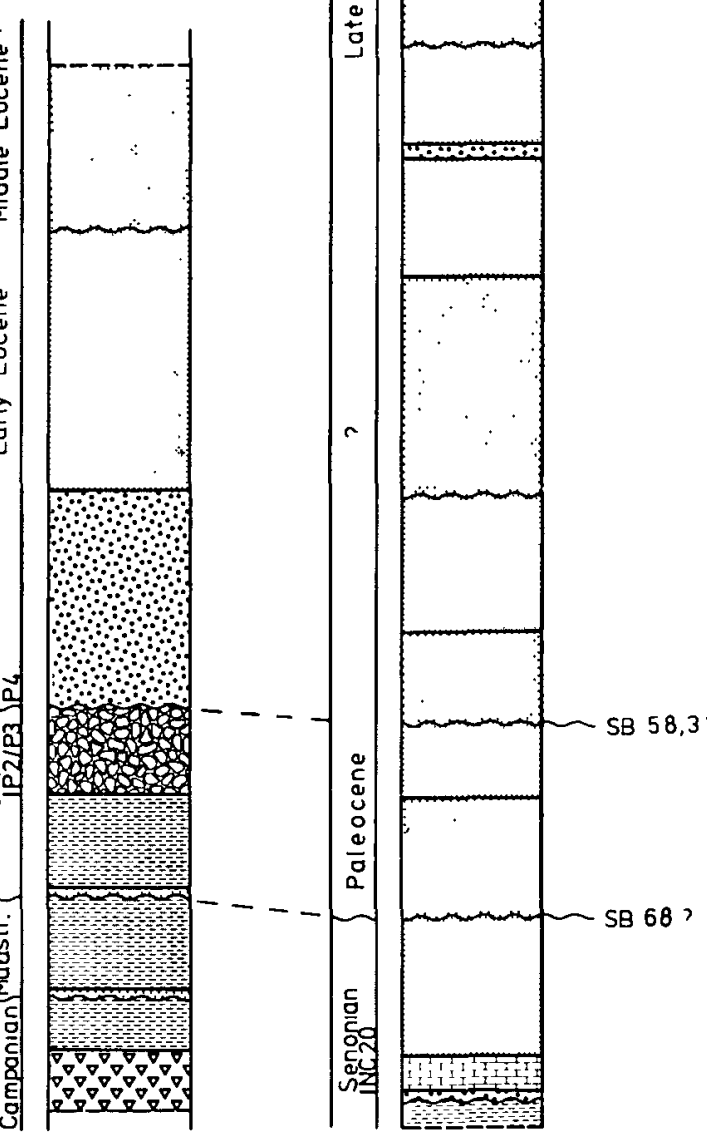

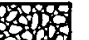

carbonate megabreccias

$\because 7$ channelized sand stones and conglo merates

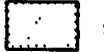

sand lobes

\section{thin - bedded}

turbidites

siliceous limestones and mudstones

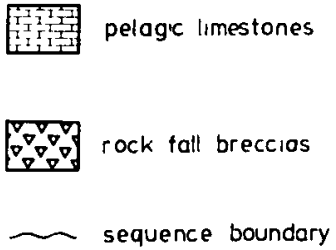

rock fall breccios

\section{calcareous}

mudstones

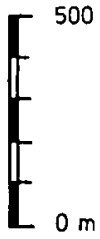

Fig. 3. Basın-wide correlation of depositıonal sequences in deep-water sediments of the inner fore-are area of southwest Nicaragua and Costa Rica. Location of columns are shown in Fig. 1. Age determinations from Schmidt-Effing (1979), Rivier (1983), Baumgartner et al. (1984), Scyfricd \& Sprechmann (1986), Sprecimann et al. (1987), Hagn (personal communication. 1989), and C. Calvo (personal communication, 1990). 
Large-scale slump and cobbly mudstone facies in the uppermost Cretaceous section indicate a slope or base of slope environment. Cobbly mudstones contain clasts of well-rounded basalts, radiolarites, and sandstones, indicating erosion of upheaved basaltic islands (see, for comparison, the chapter by Seyfried $e t$ al.). Locally, this slump apron is overlain by volcanic and carbonate breccias of early Paleocene age (Weyl, 1980; Hofherr, 1983; Calvo, 1987; Sprechmann et al., 1987). The volcanic breccias are up to $50 \mathrm{~m}$ thick and consist of dominantly pebble-sized angular volcanic rock fragments and minor constituents of neritic carbonates, hemipelagic calcilutites, and cherts (Hofherr, 1983). Up section, these volcanic breccias are overlain by carbonate megabreccias with huge blocks of shallow-water limestones, which reach maximum diametres of about $50 \mathrm{~m}$ (Calvo, 1987). The matrix is made up of calcilutites and volcanic detritus, most probably derived from reworking of periplatform deposits and erosion of the underlying strata. According to Calvo (1987), the neritic carbonates represent allodapic platform carbonates of Late Cretaceous age and are similar to the Costa Rican 'Barra Honda' platform carbonates (see chapter by Seyfried et al.). Foraminiferal biostratigraphy indicates that initial allodapic limestone deposition occurred during early Paleocene times (P1c/P2: Sprechmann et al., 1987). Upper Paleocene to middle Eocene deposits are poorly exposed and mainly consist of thin to medium-bedded turbidites. A lobe complex, which occurs within these sedimentary units, probably indicates the transition from early to middle Eocene deposits, but no biostratigraphic data are available. These lobe deposits are up to $80 \mathrm{~m}$ thick and consists of thick-bedded to massive, amalgamated sandstones, which are rich in volcanic rock fragments. Up section, they are overlain by $300 \mathrm{~m}$ of thin-bedded volcaniclastic turbidites of probably middle Eocene age (Weyl, 1980; Astorga, 1987).

The upper Eocene deposits are well exposed along the Pacific coast and consist of multicycle fan complexes. This sedimentary unit shows three cycles ranging in thickness from about 250 to $600 \mathrm{~m}$ and is characterized by well-developed channel overbank systems. Each cycle consists of a basinal unit of channelized conglomerates/sandstones, overlain by an interval of thin-bedded turbidites, interpreted as channel-associated overbank systems and overbank wedges (Mutti \& Normark, 1987). The channelized facies are commonly characterized by an upward decrease in grain size and bed thickness. Within each cycle, the channel overbank systems may consist of one or several nested channels that formed as a result of channel avulsion.

The channelized deposits are characterized by different facies:

1 Basinal minor channelized sand lobes, very rich in isolated larger Foraminifera and other shelf-derived fossils.

2 Channel-fill deposits rich in resedimented neritic carbonates and bioclasts of larger Foraminifera, corals, molluses, and echinoids.

3 Very coarse-grained channel-fill deposits, which consist of volcaniclastic conglomerates and breccias with boulders up to $4 \mathrm{~m}$ across. Debris flow deposits and high-density turbidites contain crystal-rich, juvenile volcanic detritus, indicating rapid redeposition of subaerial pyroclastic flows by subaqueous debris flows or high-density turbidity currents.

4 Sand-rich channel-fill deposits, which are associated with overbank complexes and thick overbank wedges. These sand-rich deposits consist of amalgamated sand bodies with very common loading and dewatering structures and overlie the coarser grained volcamiclastic conglomerates and/or carbonate breccias. Channel-associated overbank deposits consist of fine-grained, thin-bedded turbidities, which may be intensively current laminated. The overlying overbank wedges are characterized by thicker bedded turbidites with common progradational cycles.

\section{Section B}

An almost complete section of Upper Cretaceous to upper Eocene deposits crops out along the northwestern Pacific coast of Costa Rica. These sedimentary units were deposited close to the southern basın margin of the Nicaragua Trough and overlie a pre-Santonian basement (Baumgartner et al., 1984; see chapter by Seyfried et al.).

Sedimentation started with rock-fall brecclas of late Campanian age (Baumgartner et al., 1984). These breccias are rich in resedimented neritic carbonate clasts and pass up-section into pebbly sandstones that contain large amounts of larger Foraminifera. The breccias are overlain by $80 \mathrm{~m}$ of interbedded hemipelagic limestones and thin-bedded sandstones. The siliciclastic influx increases up section and sandstone beds become thicker. Unchannelized, thick-bedded turbidites abruptly overlie the calcareous unit. These lohe deposits consist of two major progradational cycles, separated by a small 
interval of thin to mediun-bedded turbidites. Up section the thick-bedded turbidites gradually pass into siliceous limestones and mudstones of late Paleocene to early Eocene age (Baumgartner $e t$ al., 1984). The siliceous limestones are rich in Radiolaria and planktonic Foraminifera and are similar to siliceous limestones, which formed simultaneously in the outer fore-arc region of Sámara (section E) and Cabo Blanco (section F). The middle Eocene deposits consist of thin to medium-bedded turbidites, rich in volcanic ash. The transition from the underlying lower Eocene deposits is gradational. Owing to the poor exposures of these deposits, no further data are available.

The upper Eocene deposits make up the greatest part of the sedimentary record. These sedimentary units consist, as in the northern basin area, of multicycle fan complexes and are characterized by welldeveloped channel overbank systems. Two cycles are recorded, ranging in thickness from about 600 to $700 \mathrm{~m}$. As in section A, each cycle consists of a basal unit of channelized conglomerates/sandstones, overlain by an interval of thin-bedded turbidites.

\section{Interpretation}

In the Nicaragua Trough, four sccond-order depositional sequences have been identified. Two thirdorder depositional sequences could be determined within the upper Eocene sequence of section A.

Sequence $I$ is mainly exposed in the southern Nicaragua Trough (section B) and consists entirely of unchannelized lobe deposits. The sequence boundary is indicated by the abrupt onset of sand lobes during the latest Maastrichtian at approximately the $68 \mathrm{Ma}$ sea-level fall (Haq et al., 1988). The sand lobes are interpreted to be part of the lowstand systems tract and to have formed during a rapid fall of sea level when sediment excavated from the slope and shelf were transported via submarine canyons into deep water (Posamentier \& Vail, 1988). The small thicknesses of these lobe sediments indicate that they probably were deposited close to a structural high, which deflected the bulk of the sediment from this area. The interval of thin to medium-bedded turbidites are interpreted to have formed during the late lowstand systems tract (Vail \& Sangree, 1988). Condensed sections of the transgressive/highstand systems tracts could not be determined and most probably were eroded during a subsequent fall of sea level (cf. Weimer, 1990).

In the northern basin area, sequence 1 is poorly exposed. The sequence boundary may be indicated by the occurrence of large-scale slump features and cobbly mudstone facies. However, there is no age control and debris aprons and slides have been reported also from highstand deposits and therefore may form at any time independent of the position of sea level (Weimer, 1990). The deposition of the volcanic and carbonate megabreccias during early Paleocene times is attributed to a major volcanic/ tectonic event that affected the southeastern basin margin. A previous interpretation of the emplacement of the carbonate megabreccias has been given by Calvo (1987), that these blocks detached from steep submarine fault-scarps of the Hess Escarpment. However, the association with volcanic breccias indicates that, most probably, volcanic activity and accompanying basin-margin fault activity resulted in the break up of carbonate shelf rocks, which subsequently were transported into the basin.

Sequence 2 is only exposed in section B. The sequence boundary between sequence 1 and sequence 2 most probably developed during late Paleocene times and is indicated by the onset of a new progradational lobe complex. These sand lobes are interpreted to be part of a new lowstand systems tract (Posamentier \& Vail, 1988). Up section the sandstones gradually pass into siliceous limestones and mudstones of late Paleocene to early Eocene age, indicating a rapid sea-level rise with a drastic decrease in siliciclastic sediment supply. These deposits are interpreted to be part of the transgressive and highstand systems tracts.

Sequence 3 mainly consists of thln to medium-bedded, ash-rich turbidites. In section $B$, the sequence boundary between sequence 2 and sequence 3 is indicated by the transition from siliceous limestones to siliciclastic turbidites, which occurred during the middle Eocene (Baumgartner et al., 1984) and may be correlatable with the $49.5 \mathrm{Ma}$ sea-level fall (Haq et al., 1988). Progradational and retrogradational cycles within these sequences probably indicate lowstand, transgressive, and highstand deposition.

In the northern basin area, the sequence boundary is indicated by the formation of unchannelized lobe deposits, which overlie thin to medium-bedded turbidites. These lobe deposits are interpreted as the lowstand systems tract. The overlying thin to medium-bedded volcaniclastic turbidites most probbly form part of the transgressive and highstand systems tracts, but no age control has been obtained.

Sequence 4 is characterized by multicycle fan complexes with channelized lobes, very coarse- 
grained channel-fill deposits, and thick overbank wedges. The sequence boundary between sequences 3 and 4 is indicated by the abrupt onset of coarsegrained, channelized deposits over thin-bedded turbidites, reflecting initiation of erosion and a deepmarine expression of a type 1 sequence boundary (Posamentier \& Vail, 1988).

Cycles most probably developed in response to third-order eustatic sea-level changes and are interpreted as cyclic stacks of individual lowstand systems tracts, consisting dominantly of the lowstand wedge (Posamentier \& Vail, 1988).

The high content of larger Foraminifera within channelized lobe deposits most probably reflects the resedimentation of carbonate shoals during the initial fall of sea level at the shelf margin (Shanmugam et al., 1985). Exposure of arc-fringing reefs or carbonate shelfs during the continuous fall of sea level led to the destruction and resedimentation of these systems into the basin, forming allodapic carbonate breccias, which commonly were deposited in channels.

Deposition of very coarse-grained channel-fill deposits of the lowstand systems tract occurred when major tectonic/volcanic pulses increased the supply of siliciclastic detritus and submarine canyons were deeply incised into the small shelves and/or volcanic flanks. Neritic carbonate blocks up to $10 \mathrm{~m}$ across within channels suggest the repeated destruction of basin-margin areas. Channel-overbank systems formed when lowstand deltas began to prograde during the period of lowstand wedge deposition. As the depositional slope of the delta became oversteepened and unstable, sediment failure began and large amounts of fine-grained sediments were transported into the basin, forming extensive channel overbank systems and overbank wedges. Sections of the transgressive/highstand systems tract could not be determined and were most probably eroded as sea level began to drop again and erosion and rapid sedimentation occurred in the deep water (cf. Weimar, 1990).

\section{Tempisque Trough}

The deposits of the Tempisque Trough are mainly recorded from the Barbudal area (section $\mathrm{C}$ ) and the Curú area (section $\mathrm{D}$ ) where a sedimentary unit of almost $3500 \mathrm{~m}$ is recorded. The development of sequences within this basin is strongly influenced by local parameters of volcanic and tectonic activity.

\section{Section $C$}

The oldest sediments of the Barbudal area consist of tuffs and siliceous limestones of probable early Campanian age (Seyfried \& Sprechmann, 1986). Up section, coarse-grained basaltic breccias and conglomerates occur. The basal unit of these breccias consists of weathered basalt rubble and gravel, indicating erosion of basaltic islands (see paper by Seyfried et al.). The upper units contain less-altered, probably cliff-derived basalt detritus and show intercalations of resedimented rudist debris, echinoids, oysters, corals, and larger Foraminifera. Resedimentation of these breccias occurred during the late Campanian (UC11-12; Seyfried \& Sprechmann, 1986). The breccias are overlain by a unit of thin to medium-bedded mudstones, which reach a thickness of $730 \mathrm{~m}$ and contain two intercalations of calcarenite beds, rich in neritic fossils. Deposition of these dominantly fine-grained facies persisted from terminal late Campanian until early Paleocene times (Rivier, 1983). Up section, $200 \mathrm{~m}$ of carbonate breccias and calcarenites occur. These breccias and calcarenites form small debris apronlike features and were deposited in early Paleocene times (P2/P3A; Rivier, 1983). Deposition of the carbonate sediments terminated abruptly with the onset of coarse-grained channelized conglomerates and sandstones during late Paleocene times (P4; Rivier, 1983). These channel-fill deposits consist of coarse-grained volcaniclastic conglomerates and are commonly not associated with overbank deposits. Up section they gradually pass into finer grained sandstones and calcareous mudstones. The transition from coarse-grained channelized deposits to the fine-grained calcareous turbidites occurred during the latest Paleocene (Rivier, 1983) and the lower and central parts of this fine-grained facies have been dated as early Eocene (Rivier, 1983). Up section the siliciclastic influx markedly increased and minor lobe systems formed. These lobe deposits consist of thin to medium-bedded sandstones with intercalated ash beds and pebble-sized volcanic conglomerates. Fragments of larger Foraminifera are commonly observable. The onset of these dominantly volcaniclastic deposits most probably occurred during the early middle Eocene (A. Astorga, personal communication, 1990).

\section{Section $D$}

In the Curú area, sedimentation started in the early 
Campanian with siliceous mudstones and beds of volcanic ash, which unconformably overlie the ophiolitic basement or pre-Campanian deep-water sediments (Schmidt-Effing, 1979; Lundberg, 1982; Astorga, 1987). Intercalated channelized debris-flow deposits consist of resedimented hemipelagic mudstones, locally derived neritic fossils, and minor contents of recycled material from the Nicoya Complex. Upwards, Foraminifera-rich calcareous mudstones occur. These limestones are late Campanian in age (Calcarata zone, Schmidt-Effing, 1979) and grade up-section through argillaceous limestones into thinbedded turbidites, reflecting an increasing sediment input during the early Maastrichtian. These interbedded sandstone and mudstone facies are overlain by thick lobe systems, which initially formed in the latest Maastrichtian and persisted until the late Paleocene (Lundberg, 1982; Baumgartner et al., 1984). The sand lobes consist of thick-bedded to massive sandstones, which are up to $12 \mathrm{~m}$ thick and interbedded with thin-bedded turbidites and shales. Two major progradational cycles are separated by a larger interval of thin-bedded turbidites and shales. The lobe deposits are overlain by fine-grained, thinbedded turbidite systems, which probably were deposited during latest Paleocene and early Eocene times (Astorga, 1987). During middle and late Eocene times, thick amalgamated sandstone complexes are absent and instead medium to thickbedded turbidites developed, usually forming minor thickening and coarsening upward cycles. These lobe systems are rich in larger Foraminifera and are overlain by small channelized conglomerates, composed of resedimented neritic carbonates. The top of the section is composed of thin-bedded turbidites and slump deposits.

\section{Interpretation}

In the Tempisque Trough, four depositional secondorder sequences have been identified. However, sequences vary in size, geometry, and location.

Sequence $I$ is mainly exposed in the southern basin area (section D) and consists entirely of unchannelized lobe deposits. As in section B, the sequence boundary is indicated by the abrupt onset of sand lobes during the latest Maastrichtian at approximately the $68 \mathrm{Ma}$ sea-level fall (Haq et al., 1988). These sand lobes are interpreted to be part of the lowstand systems tract. The large thickness of these lobe sediments indicates that very high sedimentation rates occurred during early Paleocene times in this area. In addition, palaeocurrent data suggest deposition by axial flows down an elongate basin, most probably supporting the development of lobe deposits. The overlying thin-bedded turbidites and shales are interpreted to have been formed during the late lowstand systems tract and probably are also parts of the transgressive and highstand systems tracts. Condensed sections could not be identified.

In the northern basin area, thick lobe deposits are absent and instead mainly fine-grained mudstones were deposited. The sequence boundary may be indicated by a thick calcarenite bed, rich in neritic fossils, reflecting a relative lowstand of sea level with erosion of shelfal sediments. Deposition of this calcarenite bed occurred during the latest Maastrichtian (Rivier, 1983) at approximately the $68 \mathrm{Ma}$ sea-level fall (Haq et al., 1988). A major volcanic/tectonic event is indicated by the formation of carbonate breccias and calcarenites on top of the sequence. According to the biostratigraphic data, deposition of these allodapic limestones could have been controlled also by the brief eustatic drop that occurred at the $63 \mathrm{Ma}$ sea-level fall (Haq et al., 1988). However, the $63 \mathrm{Ma}$ sea-level fall is also related to major global tectonic events (Schwan, 1980), and the high content of volcanic detritus calls rather for a major control on deposition by volcanic events.

In the southern Tempisque Trough, the boundary between sequence 1 and sequence 2 is indicated by the onset of a new progradational lobe complex. These sand lobes are interpreted to be part of a new lowstand systems tract (Posamentier \& Vail, 1988) that formed during the late Paleocene, probably at approximately the $58.3 \mathrm{Ma}$ sea-level fall (Haq et al., 1988). The overlying interval of thin-bedded turbidites and shales indicates a drastic decrease in siliciclastic sediment supply, most probably owing to a rapid sea-level rise. These deposits are interpreted to be part of the late lowstand systems tract as well as of the transgressive and highstand systems tract. In the northern basin area, the sequence boundary between sequence 1 and sequence 2 is indicated by the occurrence of very coarse-grained, volcaniclastic channel-fill deposits. Biostratigraphic data suggest that deposition of these channelized conglomerates occurred at approximately the late Paleocene 58.3 Ma sea-level fall (Haq et al., 1988). This channel complex is interpreted to be part of the lowstand wedge (Posamentier \& Vail, 1988). The overlying late Paleocene to early Eocene fine-grained calcareous mudstones and calcarenites are interpreted 
to have been formed during the subsequent sea-level rise and to be part of the transgressive/highstand systems tract.

The boundary between sequence 2 and sequence 3 is indicated by the onset of lobe deposits, both in section $C$ and section $D$. In section $C$ the onset of lobe deposits most probably occurred during early mid-Eocene times (A. Astorga, personal communication, 1990) and may be related to the $49.5 \mathrm{Ma}$ sealevel fall (Haq et al., 1988). In section D, no biostratigraphic control is available. The lobe deposits are interpreted to be part of the early lowstand systems tract, whereas the overlying thin-bedded turbidites most probably were deposited during the late lowstand systems tract and the transgressive and highstand systems tract. In section $\mathrm{C}$, lower sedimentation rates can be deduced from minor sediment thicknesses and the finer grained nature of the deposits.

Sequence 4 is only recorded in section D. The vertical facies arrangement of these upper Eocene sediments indicates a typical lowstand systems tract. The sequence boundary is marked by the onset of a new lobe complex, indicating sedimentation during the early lowstand systems tract. Overlying channelized conglomerates are interpreted to have been deposited during the early stage of lowstand-wedge formation. The slump and debris apron on top of the sequence are interpreted to be a part of the later stage of lowstand wedge formation, when sedimentation within channels had stopped, and sediment failure in the slope was caused by rapid progradation of lowstand deltas (Posamentier \& Vail, 1988).

\section{DEPOSITIONAL SEQUENCES IN TRENCH SLOPE BASINS}

Several small slope basins developed on the seaward margin of the outer structural high. Deposits of these trench slope basins are documented in the area of Sámara, Cabo Blanco, and Quepos (Figs 1, 4). Facies associations within the sedimentary record vary considerably and strongly depended on local conditions, such as size and location of submarine canyons as well as differential uplift/subsidence of the outer fore-arc area.

\section{Section $E$}

The oldest sediments of the Sámara area consist of siliceous mudstones and limestones of early to late Campanian age (Baumgartner et al., 1984), which unconformably overlie the basaltic basement or its cover of basaltic breccias.

From late Maastrichtian to late Paleocene times a coarse-grained submarine fan complex developed. Foraminiferal biostratigraphy indicates that the transition from calcareous limestones and mudstones to siliciclastic deposition occurred during the terminal late Maastrichtian (NC22/NC23; SchmidtEffing, 1979).

A basal lobe complex consists of unchannelized, medium to thick-bedded sandstones, which are rich in resedimented neritic fossils. These lobe deposits are overlain by channelized, chaotic mass flow deposits, including large, well-rounded andesitic boulders up to $3 \mathrm{~m}$ across and huge blocks of both Upper Cretaceous and Paleocene platform carbonates (Calvo, 1987). Up section, a further lobe complex consists of channelized, massive to thick-bedded sandstones. This lobe system initially formed during the late Paleocene (P4; Lehfeld, 1989) and is overlain by coarse-grained channel-fill deposits, which are very rich in resedimented neritic fossils and carbonate debris. These conglomerates and chaotic mass flow deposits are overlain by thin-bedded turbidites, which pass upwards into siliceous limestones and mudstones of late Paleocene to early Eocene age (Schmidt-Effing, 1979; Baumgartner et al., 1984: Lehfeld, 1989).

\section{Interpretation}

Sequence $I$ is built up by a typical lowstand systems tract with basinal lobe deposits and an overlying lowstand wedge. The sequence boundary is marked by the onset of sand lobes, indicating sedimentation during the early lowstand systems tract. The transition from mainly biogenic sedimentation to siliciclastic deposition occurred durng the terminal Maastrichtian at approximately the $68 \mathrm{Ma}$ sea-level fall (Haq et al., 1988). The overlying channelized conglomerates and chaotic mass flow deposits are interpreted to be part of the lowstand wedge. Sections of the transgressive and highstand systems tract do not occur.

The boundary between sequence 1 and sequence 2 is indicated by the deposition of a new lobe system. The onset of these lobe deposits occurred during the late Paleocene at approximately the $58.3 \mathrm{Ma}$ sealevel fall (Haq et al., 1988) and reveals sedimentation in an early stage of the lowstand systems tract. The 


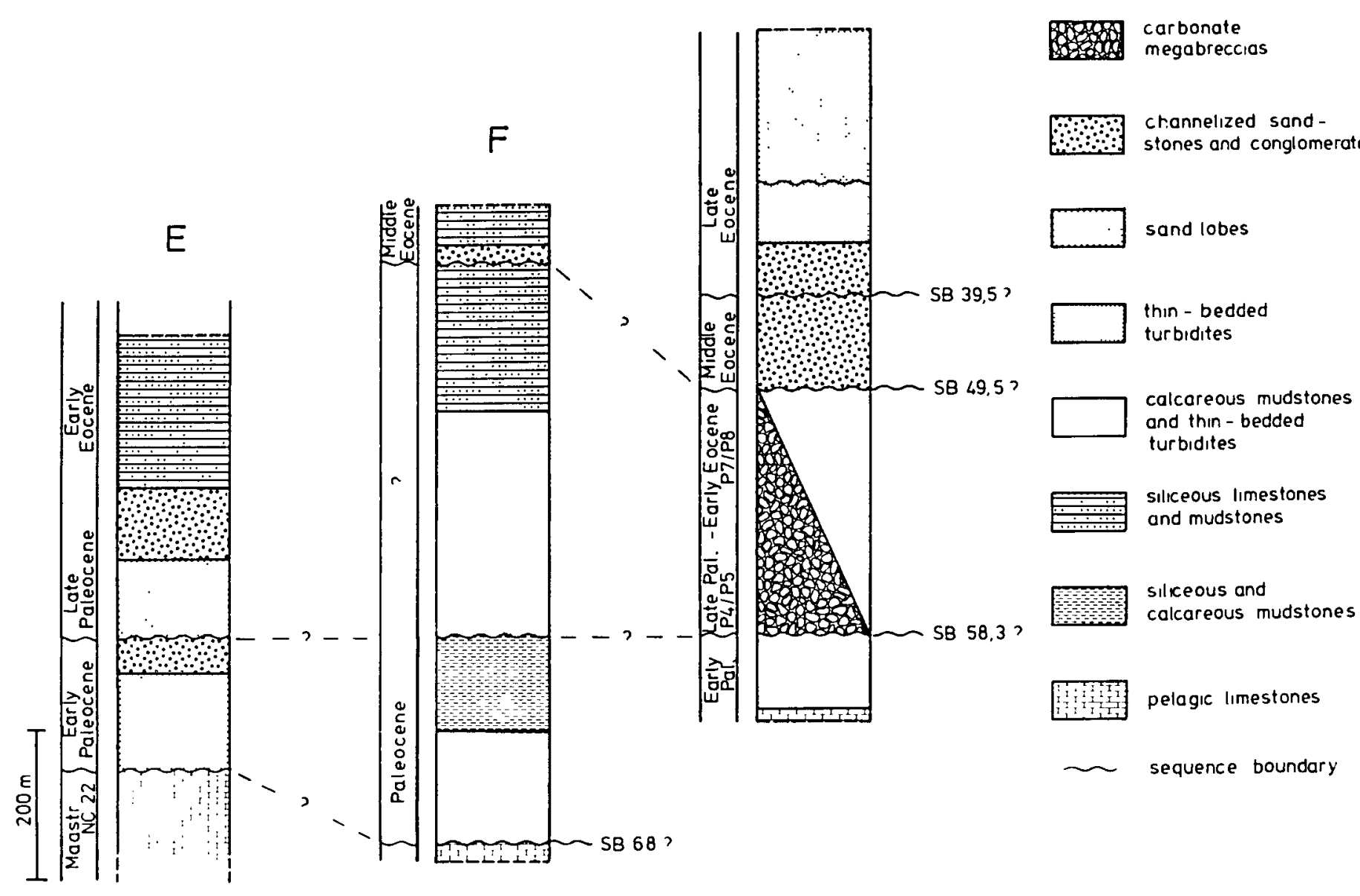

Fig 4. Basin-wide correlation of depositional sequences in deep-water sediments of the outer fore-are area of Costa Rica. Location of columns are shown in Fig. 1. Age determination from Azéma et al. (1979), Schmıdt-Effing (1979), Baumgartner et al. (1984), and Lehfeld (1989). 
overlying channel-fill deposits are interpreted to have been formed during the lowstand wedge. The increase in reef and shelf-derived shallow-water fossils indicates a relative rise of sea level, which caused a re-establishment of shallow-water production during the late lowstand wedge. The finegrained siliceous limestones and mudstones on top of the sequence reflect a rapid rise of sea level with a drastic decrease in sediment supply and are interpreted to have been formed during the transgressive and highstand systems tracts.

\section{Section $F$}

In the area of Cabo Blanco, thick siliciclastic turbidite successions are absent and biostratigraphic control is very poor. Instead, fine-grained calcareous mudstones and thin-bedded turbidites overlie the oceanic basement and Upper Cretaceous biogenic rocks (Lundberg, 1982; Baumgartner et al., 1984; Astorga, 1987).

The basinal section consists of Paleocene thin to medium-bedded siliciclastic turbidites, which are intercalated with fine-grained siliceous and calcareous mudstones (Lundberg, 1982; Baumgartner et al., 1984). Turbidites show a thickening upward trend and are overlain by siliceous and calcareous mudstones. These mudstones are thin to medium-bedded and individual beds show subtle grading of foraminiferan tests, representing locally derived hemipelagic material that was redeposited by minor currents. Up section, a new interval of interbedded mudstones and sandstones occurs. This interval is characterized by a progradational and retrogradational cycle. The uppermost section consists of siliceous limestones and mudstones of probably late Paleocene to middle Eocene age (Baumgartner et al., 1984). On top of the section, minor channelized calcarenites and conglomerates occur. These channel-fill deposits are middle Eocene in age (Baumgartner et al., 1984) and consist of resedimented neritic carbonates, isolated larger Foraminifera and volcanic rock fragments.

\section{Interpretation}

The absence of thick sand-rich turbidites suggests the occurrence of smaller submarine canyons downslope of the outer structural high that did not receive a direct supply of terrigenous detritus.

The sequence $l$ boundary is indicated by the onset of Paleocene siliciclastic turbidites over Upper Cre- taceous biogenic sediments. This transition most probably occurred during the clearly defined $68 \mathrm{Ma}$ fall of sea level (Haq et al., 1988), when coarser terrigenous sediments were also funnelled into smaller canyons of the trench slope, leading to the formation of intercalated siliciclastic turbidites and hemipelagic mudstones. The overlying fine-grained hemipelagic mudstones are interpreted to have been formed during the subsequent sea-level rise and be part of the transgressive and highstand systems tracts.

The boundary between sequence 1 and sequence 2 is marked by the new onset of siliciclastic turbidites, which probably occurred during late Paleocene times. The occurrence of these siliciclastic turbidites is related to lowstand deposition, whereas the overlying siliceous limestones and mudstones are interpreted as highstand deposits.

The boundary between sequence 2 and sequence 3 is indicated by the occurrence of channelized calcarenites and conglomerates. Lowstand deposition is marked by the appearance of significant sand- and pebble-sized volcanic material as well as the resedimentation of large amounts of larger Foraminifera, which indicate erosion of carbonate shoals during an initial fall of sea level (Sarg, 1988).

\section{Section $G$}

The Quepos section has unusual facies. Specific characteristics of this basin-fill system show close similarities with wrench-fault basins, described from the Californian borderlands (Howell et al., 1980) and the eastern Betics (Montenat et al., 1987). The depositional regime was characterized by repeated fault activity, resulting in deepening of the basin. followed by rapid erosion of borderlands and sedimentation of very coarse clastic sediments on a narrow coastal fringe of fan-deltas leading into submarine fans. Facies development is divided into coarse-grained megabreccias and small conglomeratic cones along the basin margin and a finer grained turbiditic facies along the basin axis.

Basal slope strata overlie probably accreted alkaline basalts (Sick, 1989) and basaltıc sedimentary breccias. The basaltic breccias are of early Paleocene age (Plb/PIc; Schmidt-Effing. 1979) and contain radiolarites and Late Cretaceous limestones (Azéma et al., 1979), which point to the existence of an older basement in this arca (see. for comparison. the paper by Seyfried et al.). Pelagic carbonates, which subsequently formed (P2/3A: cf. Azéma el al. 1979: 
Schmidt-Effing, 1979), indicate a very low sediment input up to the early late Paleocene.

The overlying strata consist of siliceous mudstones and thin-bedded sandstones and are very similar to the deposits of the Cabo Blanco area. The mudstones are rich in Radiolaria and planktonic Foraminifera with an up-section increase of calcareous oozes. Sandstones are mainly composed of volcaniclastic rock fragments. Some sandstones also contain basaltic and radiolaritic rock fragments, which were recycled from the Nicoya Complex.

Biostratigraphic data indicate an early Paleocene to early Eocene age (P2/P3B - P7/P8; Azéma et al., 1979; Schmidt-Effing, 1979). These dominantly finegrained deposits are associated with chaotic mass flow deposits of late Paleocene to early Eocene age (Schmidt-Effing, 1979). The chaotic mass flow deposits consist of megabreccias with huge blocks of siliceous limestones, up to $100 \mathrm{~m}$ across. Resedimented neritic carbonates are rich in larger Foraminifera of late Paleocene age and make only a minor contribution to the components. The matrix is composed of siliceous and calcareous mudstones, similar to the underlying deposits. Biostratigraphic ages fall within planktonic foraminiferal biozone P4/5 (Schmidt-Effing, 1979).

Rapid uplift in middle Eocene times resulted in the formation of small, very coarse-grained braided channel systems, which most probably were related to fan-deltas. The clast composition is still dominated by recycled material from the Nicoya Complex (basalts, cherts, and pelagic carbonates), but also includes coarse volcanic detritus, derived from the calc-alkaline arc. Age determination from resedimented larger Foraminifera indicates deposition in early middle Eocene times (Azéma et al., 1979). The coarse-grained middle Eocene deposits are overlain by upper Eocene sand-rich turbidites. These upper Eocene deposits start with coarse-grained, channelized conglomerates, which pass up-section into sand-rich channel-fill deposits. These sand-rich channel fills are associated with overbank deposits and are overlain by a thick overbank wedge. The uppermost section is composed of lobe deposits, which consist of medium to thick-bedded turbidites, rich in larger Foraminifera. Sand lobes are overlain by an interval of thin to medium-bedded turbidites.

\section{Interpretation}

Sequence $l$ is not completely exposed and consists of intercalated thin-bedded turbidites and hemipelagic mudstones. Similar to sequence 1 of section E, this deposition may indicate a lowstand during early Paleocene times, when small-sized submarine canyons received a larger amount of terrigenous material.

The boundary between sequence 1 and sequence 2 is indicated by deposition of megabreccias. These megabreccias initially formed during the late Paleocene at approximately the $58.3 \mathrm{Ma}$ sea-level fall (Haq et al., 1988). As deposition of breccias continued until early Eocene times it is suggested that tectonic control on deposition owing to uplift and tilting of the outer fore-arc was the dominant controlling factor. However, well-rounded clasts of neritic carbonates as well as basalts and radiolarites indicate erosion of neritic environments, which probably occurred because of the $58.3 \mathrm{Ma}$ sea-level fall (Haq et al., 1988) and interfered with tectonism in this area.

The boundary between sequence 2 and sequence 3 is marked by the onset of well-organized, braided channel systems. Well-rounded clasts of conglomerates and high contents of larger Foraminifera may indicate a major eustatic control on deposition.

The internal facies construction of late Eocene deposits indicates a clear eustatic control on deposition, resulting in the formation of typical lowstand systems tracts. The boundary between sequence 3 and sequence 4 is marked by the deposition of largescale channel-fill deposits and probably occurred because of the late Eocene $39.5 \mathrm{Ma}$ sea-level fall (Haq et al., 1988). The vertical development of coarse-grained channelized conglomerates and sandrich, channel overbank complexes are interpreted to be part of a lowstand wedge. Lobe deposits, which overlie the channel overbank complex, indicate a third-order sequence boundary and are interpreted to have been formed during a rapid fall of sea level and are therefore interpreted to be part of a new lowstand systems tract. The final interval of thin to medium-bedded turbidites, which overlies the lobe deposits, formed during the subsequent lowstandwedge stage.

\section{EFFECTS OF TECTONIC UPLIFT/ SUBSIDENCE, VOLCANIC SUPPLY, AND EUSTATIC FLUCTUATIONS ON DEPOSITION}

At the end of the late Maastrichtian, sedimentation 


\section{relative lowstand - moderate uplift - very high sediment input}
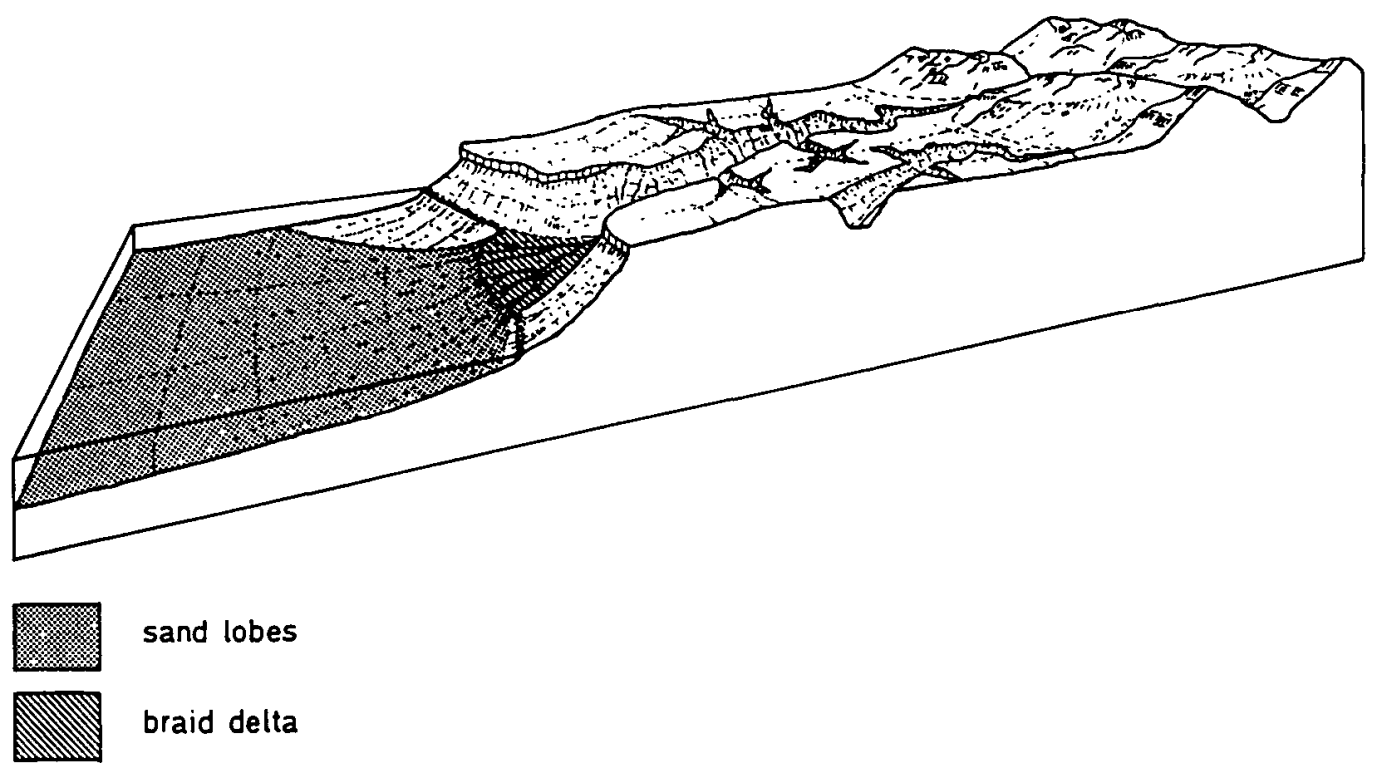

talus

Fig. 5. Very high sedimentation rates and a relative lowstand of sea-level caused the formation of thek lobe systems in the southern Tempisque Trough. This preferred development of sand-lobe systems from carly Paleocene to Eocene times was most probably favoured by a small, elongate basin shape in this area, and very high sedimentation rates during this tume may have outpaced the rate of sca-level rise during carly Paleocene times.

changed markedly, and sand-rich turbidite systems formed both in the inner and outer fore-arc troughs owing to the $68 \mathrm{Ma}$ sea-level fall (Haq et al., 1988). In the southern Tempisque Trough, extensive sand lobe systems formed. For the first time in the evolution of the island arc, there must have been a neritic system, which was able to store large amounts of sand. Lobe sedimentation persisted during the entire Paleocene with an up-section increase in grain size. The overall thickening and coarsening upward cycles within these Paleocene lobe systems indicate that a very high sediment influx, delivered from the rising calc-alkaline island arc, was able to compensate the effects of sea-level rises during Paleocene times (Fig. 5). In addition, the preferred development of sand lobe systems may have been favoured by an elongate basin shape which funnelled axial flows in this area.

In the early Paleocene, a major tectonic/volcanic event affected the northern parts of the fore-arc area. This event led to the destruction of Upper Cretaceous platform carbonates, which were deposited in both the northern Tempisque Trough and the southeastern Nicaragua Trough. The subsequent 58.3 Ma sea-level fall (Haq et al., 1988) interfered with an episode of major tectonic/volcanic activity. As a result, a coarse-grained turbidite system developed (Fig. 6). The concomitant uplift and tilting of the outer fore-arc area (see paper by Seyfried et al.) caused back-cutting of submarine canyons that deeply incised across the outer arc and headed on to the narrow shelf of the calc-alkaline arc. At the mouth of these canyons, very coarse-grained submarine fans formed in the outer fore-arc area (Fig. 7). Where smaller submarine canyons only headed on to the slope of the outer arc, locally derived mass flow deposits and thin-bedded turbidites prevailed. 


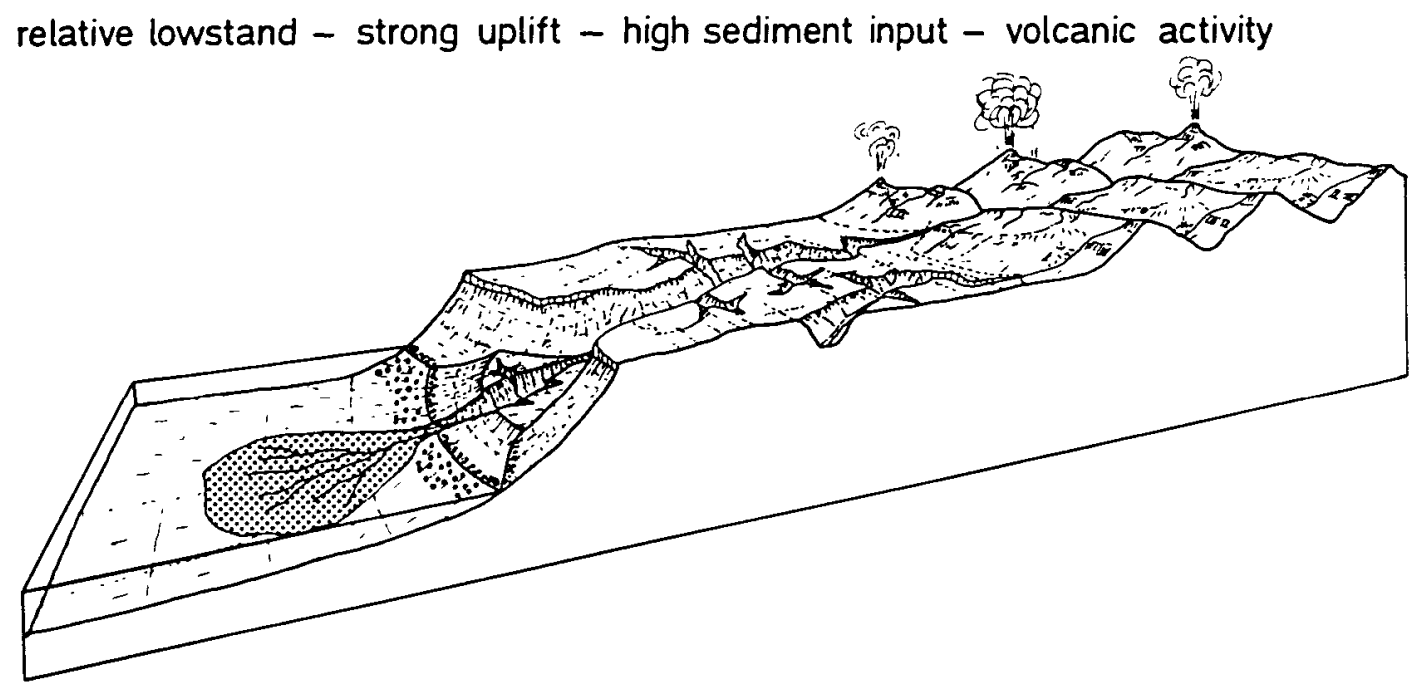

coarse to very coarse

channel-fill deposits

scarp breccias, boulder avalanches

Fig. 6. Strong uplift, high sedimentation rates, and a relative lowstand of sea level caused the formation of channelized lobes and very coarse-grained channel-fill deposits in the inner fore-are area of southwest Nicaragua and northwest Costa Rica during the late Palcocenc and late Eocene.

The subsequent sea-level rise in the latest Paleocene and the early Eocene is mainly documented by retrogradational cycles. In addition, the calc-alkaline arc was largely inactive throughout late Paleocene to early Eocene times and contributed only minor volcaniclastic sediments to the basins. In the inner fore-arc troughs, thin-bedded turbidites formed where siliciclastic neritic systems persisted, whereas siliceous mudstones and limestones developed when carbonate ramps were establised (Fig. 8). The uplift of the outer structural high during the late Paleocene closed the Sámara bypass area (see paper by Seyfried $e t a l$.) and subsequently only fine-grained siliccous mudstones and limestones were deposited in the outer fore-arc basins. Carbonate ramps, concomitantly developed on the outer structural high, periodically delivered neritic carbonate material to the lower slope (Fig. 9). In the southern outer arc, tectonic uplift and major fault activity persisted until the middle Eocene and caused the formation of chaotic megabreccias and small-scale braided fan systems, which were related to fan-deltas.

In middle Eocene times, volcanic activity in- creased again and ash-rich sediments were deposited in the inner fore-arc basins. Common resedimented larger Foraminifera indicate the persistence of neritic carbonate systems upon the shelf. Small to moderate drops of sea level are documented by the formation of minor siliciclastic slope fans, rich in resedimented larger Foraminifera (Fig. 10).

During the early late Eocene, volcanic/tectonic activity intensified and very coarse-grained submarine fan systems formed. Fragmentation of the basin margin caused the destruction and redeposition of patch reefs, which were resedimented into the adjacent basins (Fig. 6). The formation of repetitive channel overbank complexes in this depositional sequence is interpreted to be the result of thirdorder eustatic sea-level fluctuations when the strong volcanic/tectonic activity had decreased (Fig. 11).

\section{CONCLUSIONS}

The formation of depositional sequences in the deepwater sediments of southern Central America is 


\section{relative lowstand - strong uplift - high sediment input - volcanic activity}
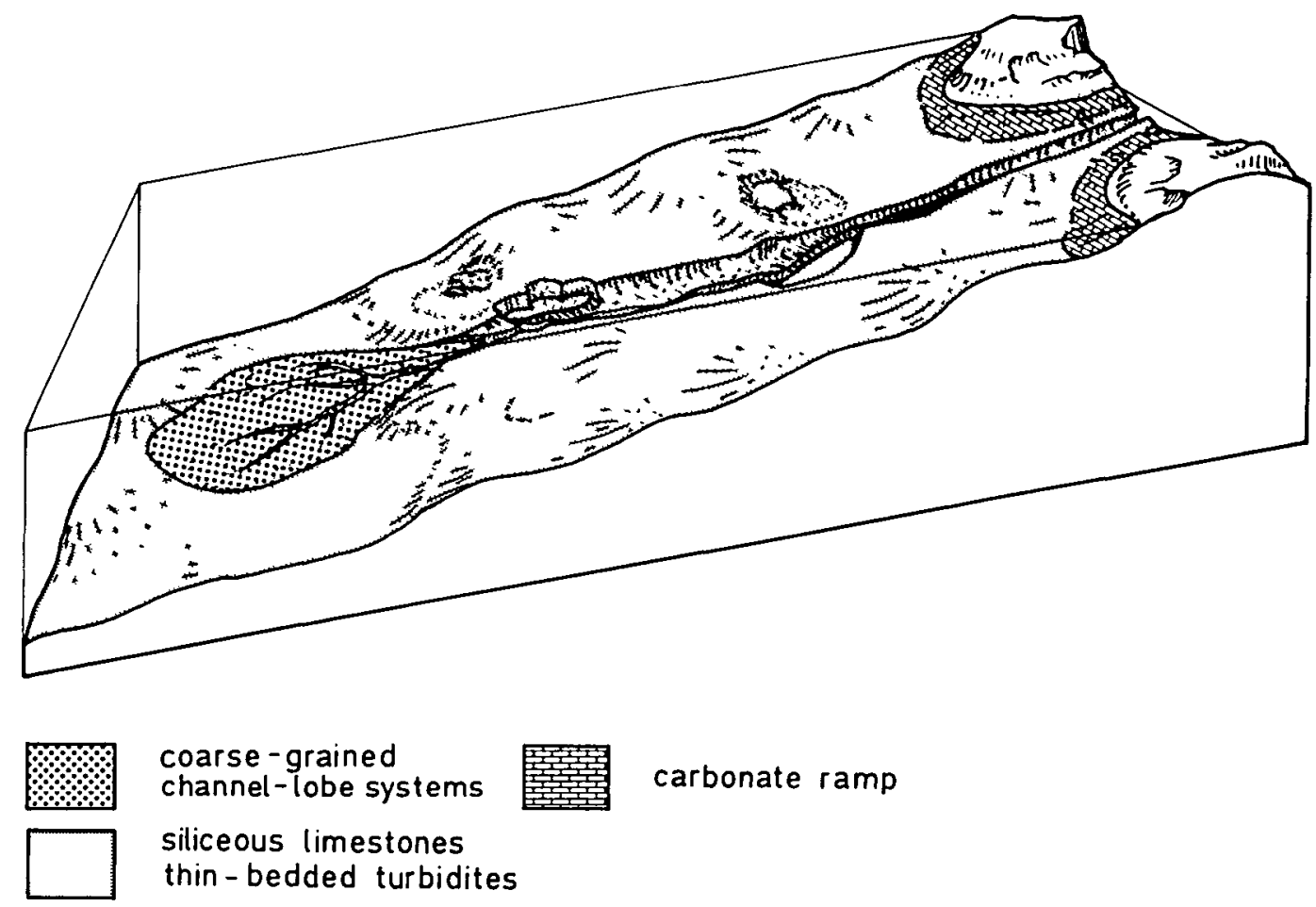

$$
\begin{aligned}
& \text { coarse-grained } \\
& \text { channel-lobe systems } \\
& \text { siliceous limestones } \\
& \text { thin-bedded turbidites }
\end{aligned}
$$

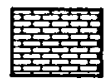

carbonate ramp

Fig. 7. A model for submarine fan sedimentation in the outer fore-arc during the early Paleocene and earliest late Paleocene. Strong uplift of the fore-arc area. high sedimentation rates, and a relative lowstand of sca level caused the formation of sand lobes and very coarse-grained channel-fill deposits in the outer fore-arc area, where submarine canyons deeply incised into the outer are and headed on to the narrow shelf of the volcanic arc. Where smaller submarine canyons only headed on to the slope of the outer arc, locally derived mass flow deposits and thin-bedded turbidites prevaled.

strongly related to the morphotectonic evolution of the island-arc system. Each depositional sequence reflects the complex interaction between global sealevel fluctuations, sediment supply, and tectonic activity. Sediment supply and tectonic activity overprinted the eustatic effects and enhanced or lessened them. If large supplies of clastics or uplift overcame the eustatic effects, deep marine sands were also deposited during highstand of sea level, whereas under conditions of low sediment input, thin-bedded turbidites were deposited even during lowstands of sea level.

The internal facies architecture of depositional sequences can be reduced strongly, and recognition of transgressive and highstand systems tracts may be uncertain, where outcrop data do not allow determination of the larger scale stratal pattern or potential condensed sections are eroded. Thirdorder depositional sequences could be determined only when high rates of sedimentation and subsidence occurred.

Though lowstands of sea level favour the development of turbidite or fan systems, the amount and type of sediments will significantly influence the type and timing of turbidite events. Very coarse channellobe systems will only form in mature island-arc systems when simultaneous tectonic uplift and high volcanic activity occur in addition to sea-level lowering. During periods of tectonic and volcanic quiescense, fine-grained, thin-bedded turbidite systems prevail even during lowstands of sea level.

Remarkable changes in sedimentation occurred 


\section{relative highstand - tectonic quiescence - low sediment input}

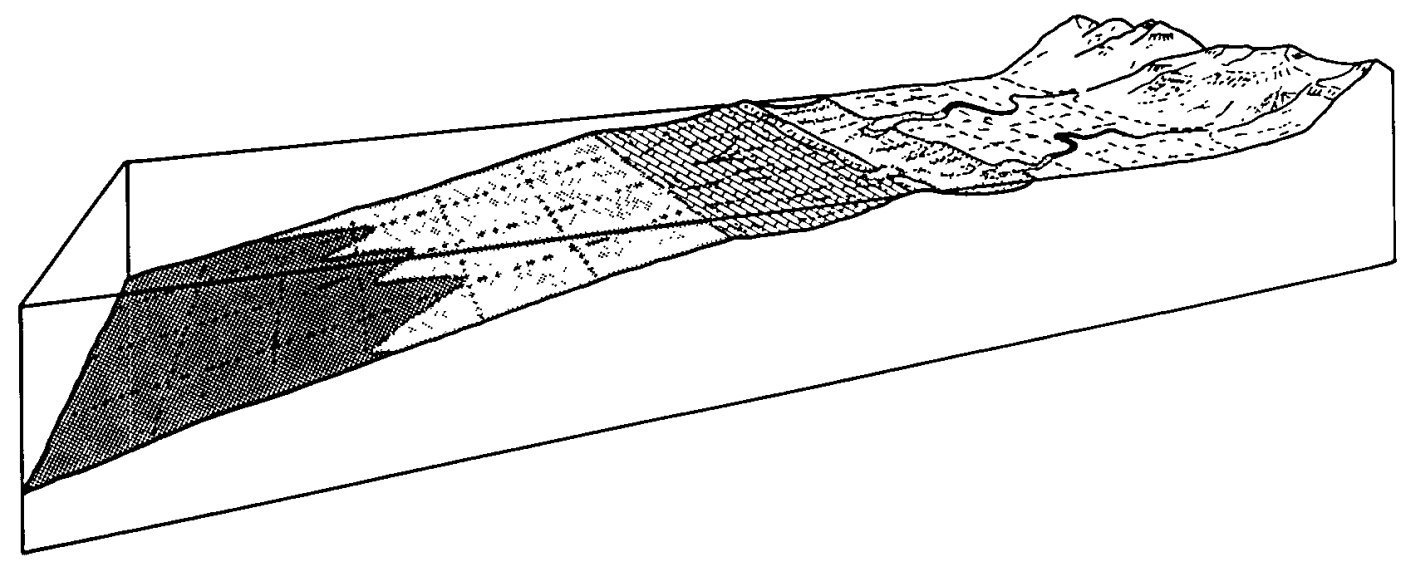

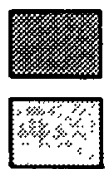

siliceous mud

carbonate oozes

carbonate ramp

(forams + red algae)
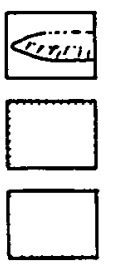

barrier sands

estuary

flood plain

Fig. 8. A relative highstand of sea level, tectonic quiescense, and low sedimentation rates during late Paleocene to early Eocene times caused the formation of siliceous mudstones and limestones in the inner fore-arc basins, where carbonate ramps became established. Where siliciclastic neritic systems persisted, thin-bedded turbidites formed in the adjacent basin arcas.

when tectonic/volcanic pulses and second-order cycles of eustatic fluctuation interfered. Therefore, uplift and subsidence of sediment-source areas acted as major controls on deposition of basinal cycles. Alternate immersion and exposure of the carbonate shelf that supplied the shallow-water carbonate sediments into the fore-arc basins caused long-term hybrid siliciclastic-carbonate basin cycles. The abruptness of lithologic transitions between carbonate breccias and siliciclastic deposits suggests that resedimentation of carbonate breccias mainly occurred owing to tectonic/volcanic events. Siliciclastic sedimentation indicates that most detritus reached the deep sea during relative sea-level lowstands, when the sediment bypassed subaerially exposed shelves. Basinal siliciclastic sedimentation decreases when most of the detritus was trapped in inner shelf environments. During relative highstands, mud- and sand-sized carbonate sediment was shed off neritic carbonate systems and transported into the fore-arc basins, resulting in increased carbonate contents in the basinal sediments. Conversely, during sea-level lowstands, subaerial exposure of platforms caused meteoric cementation and karstification and, as a result, only a little mud- and sand-sized carbonate shelf detritus reached the deep sea. In ramp settings a sea-level fall exposes only the upper parts of carbonate ramp systems and production of shallowwater carbonate sediment continues in the outer ramp environment (Shanmugam \& Moiola, 1985: Sarg, 1988; Dolan, 1989). Such moderate or initial lowstands are documented by grainflow deposits and turbidites, rich in larger Foraminifera.

The most striking feature is the almost simultaneity of tectonic/volcanic activity and second-order cycles of eustatic sea-level fluctuations during Late Cretaceous, Paleocene, and mid-late Eocene times.

Many causes have been proposed for changes in global sea levels, by changing either the total volume of sea water or the total volume of the oceanic 


\section{relative highstand - tectonic quiescence - low sediment input}
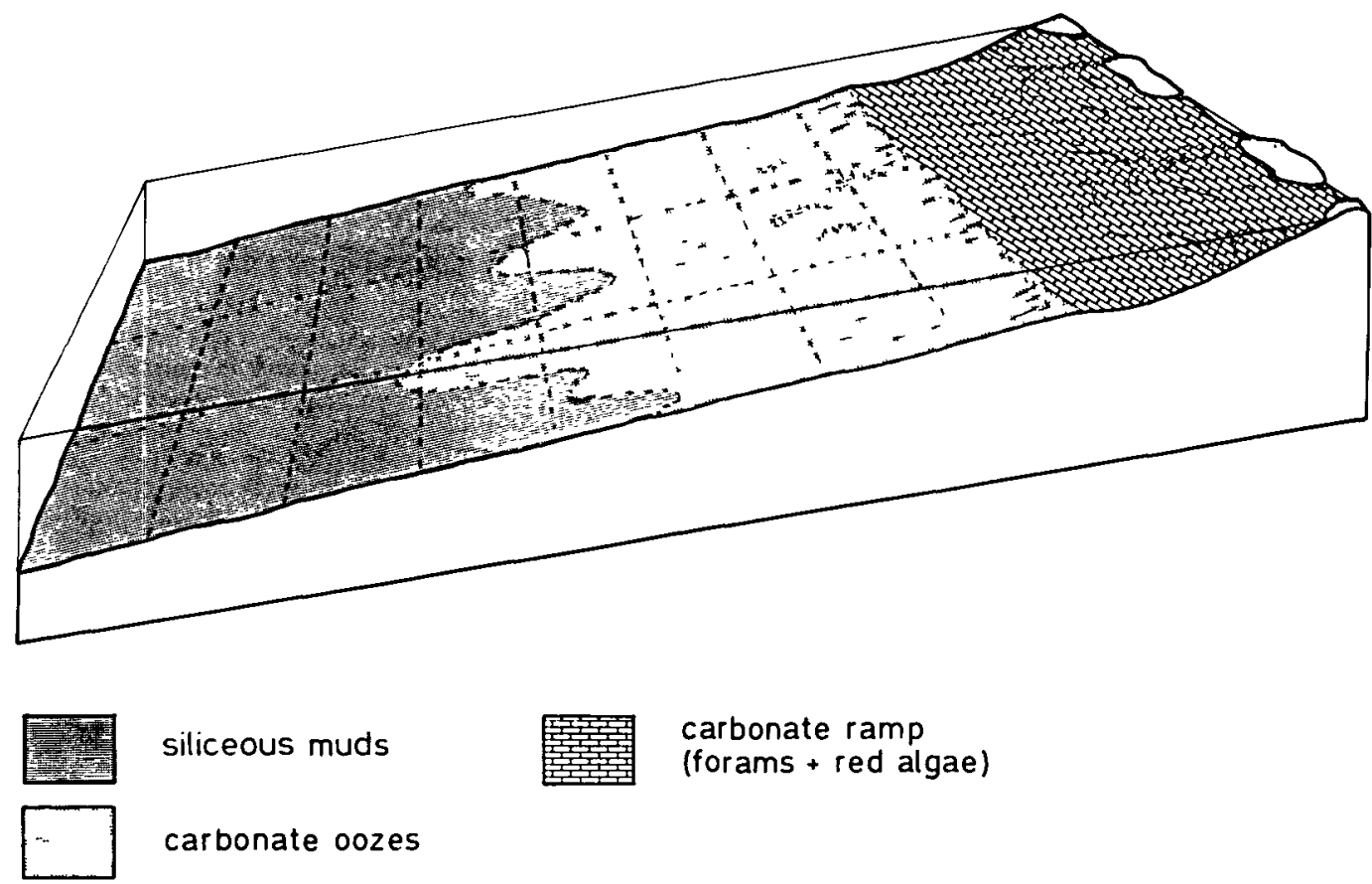

siliceous muds

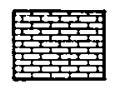

carbonate ramp

(forams + red algae)

\section{carbonate oozes}

Fig. 9. A relative highstand of sea level, tectonic quiescense, and low sedimentation rates caused the formation of siliceous mudstones and limestones in the outer fore-arc basins dunng late Palcocene to middle Eocene times. Carbonate ramps. which concomitantly developed on the outer structural high, periodically delivered neritic carbonate matenal to the lower slope.

basins (Pitman, 1979; Howell \& von Huene, $1980 ;$ Miall, 1984). Cloetingh (1988) proposed a tectonic mechanism for apparent sea-level fluctuations with a maximum magnitude of a few hundred metres. According to this model, tectonically induced vertical motions of the lithosphere may cause third-order cycles. Larger fluctuations in apparent sea level could be related to major reorganizations of lithospheric stress fields owing to rifting and fragmentation of plates, dynamic changes at convergent plate boundaries, or collision processes. Schwan (1980) compiled data showing that world-wide orogenic activity in the Late Jurassic to Recent, including the development of unconformities and compressional structures, metamorphic and plutonic episodes, could be correlated with major readjustments in the world plate patterns.

Late Cretaceous to late Eocene drift rates calculated from the North Atlantic Ocean correlate closely with global orogenic phases which in turn coincide with crustal movements in Central America. These episodes of major global tectonic/volcanic activity occurred at $80-75,63,55-53$, and $42-38 \mathrm{Ma}$ and agree with major tectonic and volcanic pulses in Central America (see paper by Seyfried et al.). This corroborates that global tectonic processes play an important role in generating major sea-level fluctuations and hence in the formation of depositional sequences.

\section{ACKNOWLEDGEMENTS}

This study was supported by the Deutsche Forschungsgemeinschaft (DFG; Se 490/1-1, Se 490/13 ). The field trips were sponsored by grants of the Deutscher Akademischer Austauschdienst (DAAD). The research in Costa Rica was further 


\section{relative highstand - slight uplift - low sediment input - volcanic activity}

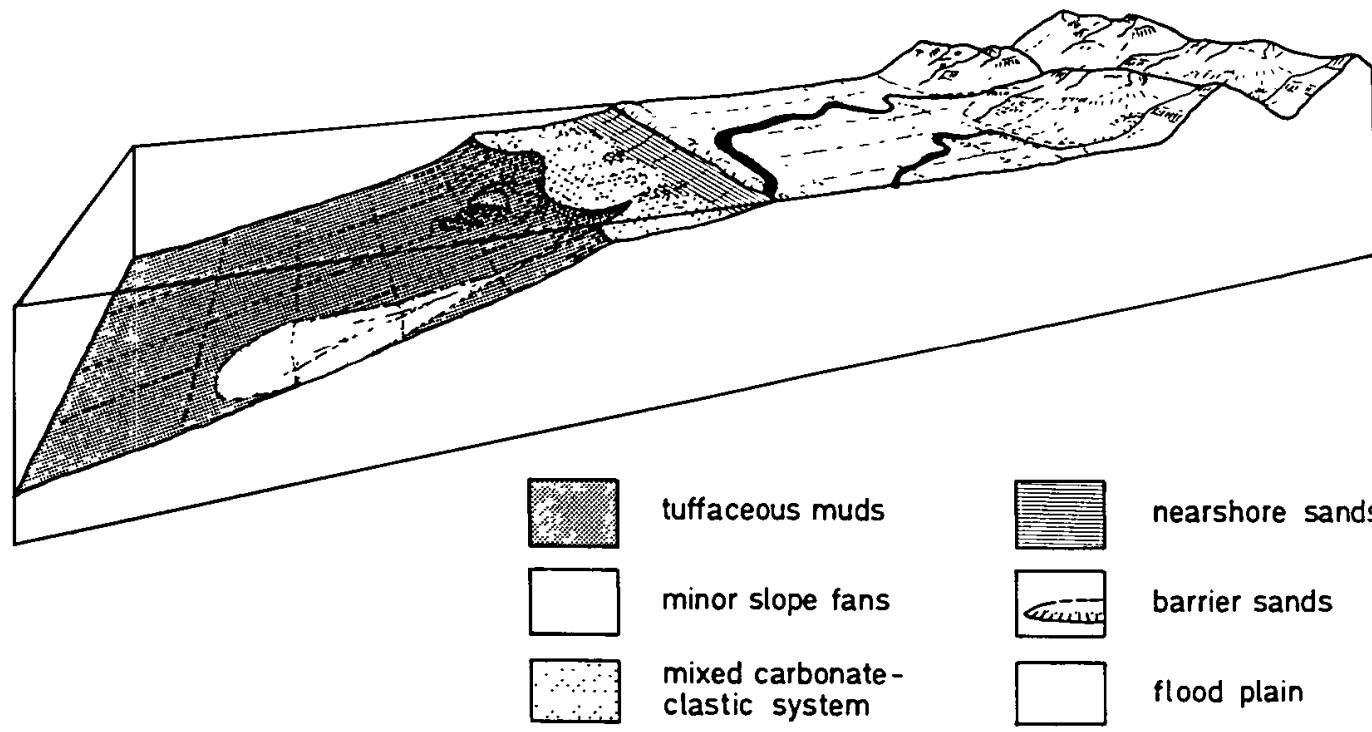

Fig. 10. A relative highstand of sea level, slight uplift, and low sedimentation rates dunng the middle Eocene led to the formation of tuffaccous mudstones as well as thin-bedded turbidites. Smaller slope fans developed as a result of a minor sea level lowstand or a local increase in volcaniclastic supply.

relative lowstand (rising sea level) - tectonic quiescence - high sediment input

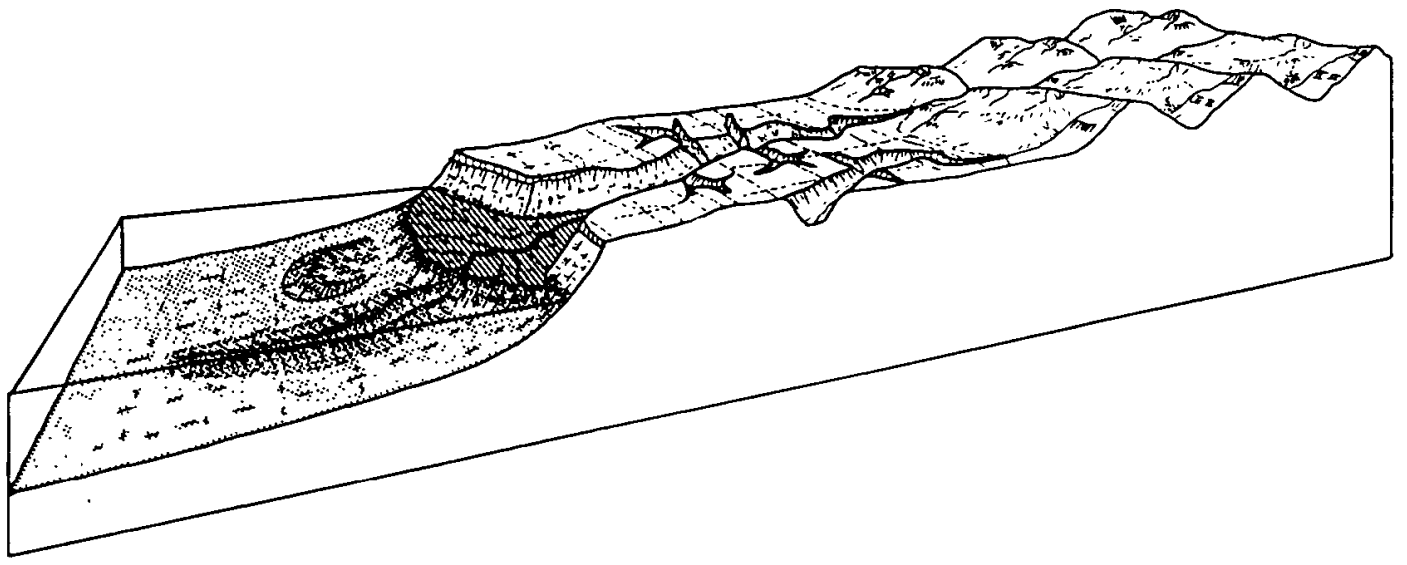

lowstand delta

channel - overbank systems, slumps, chaotic mass-flow deposits, basin-plain turbıdites

Fig. 11. A relative rise of the sea level in late Eocene times changed the coarse-grained sedimentation shown in Fig. 6 and channel overbank systems developed. Overbank deposits and overbank wedges are rich in organic material and must have been related to lowstand deltas. 
supported by the close cooperation with the national oil company of Costa Rica (RECOPE) and the Department of Geology, University of Costa Rica. Transport facilities and field support were further provided by the Instituto Nicaraguense de la Minería (INMINE). We would like to thank David Macdonald (British Antarctic Survey) for his helpful comments and review of this paper.

\section{REFERENCES}

Astorga, A. (1988) Geodinámica de las cuencas del Cretácico Superior-Paleógeno de la region 'forearc' del sur de Nicaragua y norte de Costa Rica. Rev. Geol. Am Central 9, $1-40$.

Astorga, A., Fernandez, J., Barboza. G.. Campos, L., Obando, J., Aguilar, A. \& Obando. L. (1989) Cuencas sedimentarias de Costa Rica: evolución Cretácico Superior-Cenozoica y potencial de hidrocarburos. Transactions of the Fourth Circum-Pacific Council for Energy and Mineral Resources Conference, Abstr. Vol., San José, pp. 1-18.

Azéma, J., Glacon, G., Tournon. J. \& Vila, J.-H. (1979) Precisiones acerca del Palcoceno de Puerto Quepos y sus alrededores. Provincia de Puntarenas, Costa Rica. Inst. Geogr. Nac., Inf. Semestr. Julo-Dic. 1979, 77-88.

Barnes, N.E. \& Normark, W.R. (1985) Diagnostıc parameters for comparing modern submarine fans and ancient turbidite systems. In: Submarine Fans and Related Turbidite Systems (Eds Bouma. A.H., Normark. W.R. \& Barnes, N.E.) pp. 13-14. Springer-Verlag. New York.

Baumgartner, P.O., Mora, C.R., Butterlin, J., Sigal, J., Glacon, G., Azéma, J. \& Bourgots, J. (1984) Sedimentación y paleogeografia del Cretácico y Cenozoico del litoral pacífico de Costa Rica. Rev. Geol. Am. Central 1, 57-136.

Burbach, G., Frohlich, C., Pennington, W. \& Matumoto, T. (1984) Scismicity and tectonics of the subducted Cocos Plate. J. Geophys. Res. 81, 31-63.

Calvo, C. (1987) Las calizas neriticas de la vertiente Pacifica del norte de Costa Rica y sur de Nicaragua: epocas y sistemas de sedimentación asociadas, con la apertura y evolución del margen convergente de la América Central meridional. Unpublished tesıs de Licenciatura, University of Costa Rica, San José, 165 pp.

Cloetingh, S. (1988) Intraplate stresses: a tectonic cause for third-order cycles in apparent sea-level? In: Sea-level Changes: an Integrated Approach (Eds Wilgus, C.K., Hastıngs, B.S., Kendall, C.G.St.C., Posamentier, H.W., Ross, C.A. \& van Wagoner, J.C.) Soc. Econ. Paleontol. Mineral., Spec. Publ. 42, $18-29$.

Dolan, J.F. (1989) Eustatic and tectonic controls on deposition of hybrid silıciclastic/carbonate basinal cycles: discussion with examples. Bull., Am. Assoc. Petrol. Geol. $73,1233-1246$.

Gursky, H.-J. (1984) Die Sedimentgesteme in ophlolithuschen Nicoya-Komplex (Oberjura bis Alt-Tertiar von
Costa Rica): ihre Verbreitung. Fazies und geologische Geschichte mu besonderer Berucksichtigung der Radiolarite. Unpublished dissertation, University of Marburg. 394 pp.

Haq, B.U., Hardenbol, J. \& Vall, P.R. (1988) Mesozoic and Cenozoic chronostratigraphy and eustatic cycles. In: Sea-level Changes: an Integrated Approach (Eds Wilgus. C.K., Hastings. B.S., Kendall, C.G. St. C., Posamentier. H.W., Ross. C.A. \& van Wagoner. J.). Soc. Econ. Paleontol. Mineral., Spec. Publ. 42. 71-108.

Hofherr, G. (1983) Geología de las calizas de Sapoá. Inf. Final Proy. 05. Unidad Geol. COMNOMET (unpublished). Instituto Nicaraguense de la Minería (INMINE), Managua, $53 \mathrm{pp}$.

Howell. D.G. \& Von HuEne, R. (1980) Tectonics and sediment along active continental margins. Soc. Econ. Paleont. Miner., Short Course, San Francisco, 1980.

Howell, D.G.; Craich, J.K., Greene, H.G., McCulloch, D.S. \& VeDDER, J.G. (1980) Basin development along the latc Mesozoic and Camozoic California margin: a plate tectonic margin of subduction, oblique subduction and Iransform tectonics. In: Sedimentation in obliqueslup Mobule Zones (Eds Ballance, P.F. \& Reading. H.G.) Spec. Publ. Int. Ass. Sediment. 4, 43-62.

Kolla, V. \& Macurda D.B.. JR. (1988) Sca-level changes and timing of turbidity-current events in decp-sea fan systems. In: Sea-level Changes: an Integrated Approach (Eds Wilgus, C.K.. Hastıngs, B.S., Kendall, C.G. St. C.. Posamentter, H.W., Ross, C.A. \& van Wagoner, J.). Soc. Econ. Palcontol Mineral., Spec. Publ. 42. $381-392$.

LEHFELD, H. (1989) Biostratigraphie und taxonomische Untersuchungen an planktonischen Foramunferen aus dem Alt-Tertiar-Profil von Garza bel Samara (Prov. Guanacaste, $C R$.). Unpublished Diplomarbcit, University of Marburg. $68 \mathrm{pp}$.

LUNDBERG. N. (1982) Evolution of the slope landward of the Middle America Trench. Nicoya Peninsula, Costa Rica. In: Trench-Forearc Geology (Ed. Leggett, J.K.). Geol. Soc. London. Spec. Publ. 10. 133-147.

Minle, A.D. (1984) Principles of Sedimentary Basm Analysis. Springer-Verlag, New York, 490 pp.

Mitchum, R.M. (1985) Seismic stratigraphic expression of submarine fans. In: Sessmic Stratigraphy. II: an Integrated Approach to Hydrocarbon Exploration (Eds Bcrg. O.R. \& Woolverton. D.G.). Mem.. Am. Assoc. Petrol. Gcol. 39. 117-136.

Montenat, C.. Ott d’Estevou, P., Larouziere, F.D. \& BEDu, P. (1987) Origınalıté géodynamique des bassıns néogènes du domaine bétıque onental. Notes Mém. Total Co. Fr. Pétrole 21, 11-49.

Murn, E. (1985) Turbudite systems and their relations to deposituonal sequences. In: Provenance of Arenites (Ed. Zuffa. G.G.) pp. 65-93. D. Reidel. Dordect.

MUTm. E. \& Normark. W.R. (1987) Comparing cxamples of modern and ancient turbidite systems: problems and concepts. In: Marıne Clasuc Sedimentology (Eds Leggett. J.K. \& Zuffa. G.G.) pp. 1-38. Graham \& Trotman. London.

Pitman, W.C.. Ill (1979) The effect of eustatic sca level changes on stratıgraphic sequences at Atlantic margins. Mem. Am. Assoc Petrol. Geol. 29, 453-460.

Posamentitr, H W \& Vall. P R. (1988) Eustatic controls 
on clastic deposition. 11 - sequence and systems tract models. In: Sea-level Changes: an Integrated Approach (Eds Wilgus, C.K., Hastings, B.S., Kendall, C.G. St. C., Posamentier, H.W., Ross., C.A. \& van Wagoner, J.). Soc. Econ. Paleontol. Mineral., Spec. Publ. 42, 155- 181 .

Rıvier, F. (1983) Sintesis geológıca y mapa geológico del área del bajo tempisque, Guanacaste, Costa Rica. Inst. Geogr. Nac., Inf. Semestr. Enero-Junto, 1983, 7-30.

SARG. J.F. (1988) Carbonate sequence stratigraphy. In: Sea-level Changes: an Integrated Approach (Eds Wilgus, C.K. . Hastings, B.S., Kendall, C.G. St. C., Posamentier, H.W., Ross, C.A. \& van Wagoner, J.). Soc. Econ. Paleontol. Mincral., Spec. Publ. 42, 155-181.

Scumidt-Effing, R. (1979) Alter und Genese des NicoyaKomplexes, eıner ozeanischen Paláokruste (Oberjura bis Eozan) im sudlichen Zentralamerika. Geol. Rundsch 68(2), 457-494.

Schwan, W. (1980) Geodynamic peaks in Alpino-type orogenesis and changes in occan-floor spreading during Late Jurassic-Late Tertiary time. Bull., Am. Assoc. Petrol. Geol. 64, 359-373.

Seyfried, H. \& Sprechmann, P. (1986) Über die Fruhgeschichte (Campan bis Eozan) der sudlichen mittclamerikanischen Landbrucke. Neues Jahrb. Geol. Palaeontol. Monatsh. 1986, 38-55.

Shanmugam, G. \& Molola, R.J. (1988) Submanne fans: characteristics, models, classification, and reservoir potential. Earth Sci. Rev. 24, 383-428.

Shanmugam, G., Molola, R.J. \& Damuth, J.E. (1985)
Eustatic control of submarine fan development. In: Submarıne Fans and Related Turbidite Systems (Eds Bouma, A.H., Normark, W.R. \& Barnes, N.E.) pp. 23-28. Springer-Verlag, New York.

Sick, M. (1989) Paleomagnetism of the Ophiolite Complexes from the southern Middle America land-bridgc (Costa Rica and Panamá). Tübınger Geowıss. Arb. 4, $1-108$.

Sprechmann, P., Astorga, A., Bolz, A. \& Calvo, C. (1987) Estratigrafía del Cretácico de Costa Rica. In: El Cretáctco de México y América Central (Eds Barbann. J.M., Gursky, H.-J. \& Meiburg, P.). Actas Fac. Cienc. Tierra, Univ. Autonoma Nuevo Lcón. Linares 2. $251-260$.

Stow, D.A.V., Howell, D.G. \& Nelson, C.H. (1985) Sedimentary, tectonic, and sca-level controls. In: Sub. marine Fans and Related Turbidte Systems (Eds Bouma, A.H., Normark, W.R. \& Barnes, N.E.) pp. 15-22 Springer-Verlag. New York.

Vall, P.R. \& Sangree, J.B. (1988) Sequence stratigraphy concepts. Short course in conjunction with the 'Sequence, Straugraphy, Sedimentology, Surface and Subsurface' Conference, Course Notes. Can. Soc. Petrol. Geol., Calgary, September 1988.

Weimer, P. (1990) Sequence stratigraphy, facies geometries, and depositional history of the Mississippi Fan, Gulf of Mexico. Bull., Am. Assoc. Petrol. Geol. 74. 425-453.

WeyL, R. (1980) Geology of Central America. Gebr. Borntraeger, Berlin, $371 \mathrm{pp}$. 